\title{
Maritime Traffic on Approach to Port of Split and Assessment of Collision and Grounding Risk
}

\author{
Zvonimir Lušića, Danijel Pušićb, Mirko Čorića
}

The Port of Split is the largest Croatian passenger port and its access fairways, characterized by a very high likelihood of accidents, especially of collisions and groundings, the busiest in the Croatian part of the Adriatic. This paper analyzes the main access fairways to the Split City Port, as well as those leading to the Kaštela Bay and the North Port of Split. Small vessel maritime traffic is also analyzed, although it is neither continuous, nor follows any established main routes. The AIS vessel movement data served as the basic source of data for larger vessels, and arrival/departure reports of port authorities for other maritime traffic. Main access fairways, maritime traffic concentration and structure, as well as assessment of collision and grounding risk are defined in keeping with the obtained data.

\section{KEY WORDS}

$\sim$ Port of Split

$\sim$ AIS traffic

$\sim$ Likelihood of collision and grounding

a. University of Split, Faculty of Maritime Studies, Split, Croatia

e-mail: zlusic@pfst.hr

b. Hydrographic Institute of the Republic of Croatia - Split, Split, Croatia

e-mail: danijel.pusic@hhi.hr

\section{INTRODUCTION}

The Port of Split is situated in the central Adriatic, recessed deep behind an island area. It can be accessed through the Split Channel to the west, Brač Channel to the east and the Split Gates strait to the south. The Split Channel to the west is accessed from the Drvenik and Šolta Channel. The Split Gates strait is the shortest, busiest and narrowest access fairway to the Port, which makes it one of the most dangerous access points to the Port of Split. Fairways passing through the Drvenik and Šolta Channel and the Split Gates converge into a single narrow area immediately in front of the Port, also intersected by the fairways leading to ports in the Kaštela Bay and coastal transit routes. The area is in the immediate vicinity of marinas and boat docks, the traffic from which intersects with the navigational routes of larger vessels, especially in the summer.

Since data on the movement of larger vessels are available from the AIS (Automatic Identification System), they will be used to determine the potential number of collisions and groundings by analytical methods, i.e. to estimate the actual annual number of collisions and groundings based on their subsequent correction. Calculations will be made by the IWRAP computer program. Assessment of the likelihood of collisions and groundings will be based on the calculation of the potential number of accidents (Na-number of collisions and groundings which will occur if the crew fail to take appropriate evasive maneuvers). The actual number of collisions and groundings ( $\mathrm{Nc}$ and $\mathrm{Ng}$ ) will be obtained by multiplying the potential number of accidents with a corresponding coefficient of likelihood $(P C)$, which may be defined as a correlation between actual and potential accidents. The coefficient will be borrowed from other authors, in the form determined for similar areas and conditions of navigation. 
Collisions:

(Nc) collision $=\mathrm{Na} \cdot \mathrm{Pc}$

$\mathrm{Nc}$ - Number of collisions, $\mathrm{Na}$ - Potential number of collisions, $\mathrm{Pc}$ - Conditional likelihood of collision

Groundings:

$(\mathrm{Nc})$ groundings $=\mathrm{Nq} \cdot \mathrm{Pci}$

$\mathrm{Ng}$-Number of groundings, $\mathrm{Nq}$-Potential number of groundings, $\mathrm{PCi}$ - Conditional likelihood of grounding.
Data on the likelihood of collision and grounding obtained by the IWRAP will then be compared to assessments based on accident statics. Assessments based on AIS data will be supplemented to account for the influence of smaller vessels on the likelihood of collision and grounding.

\section{MARITIME TRAFFIC IN THE PORT OF SPLIT}

In 2013, 15,805 vessels entered the Port of Split (City and North), approximately $6 \%$ of which were international traffic (Izvješće lučkih kapetanija, 2014). Over 40 vessels can thus be surmised to arrive at the Port of Split, i.e. pass in its immediate vicinity (annual average), on a daily basis. AIS data suggest the same (Figure 1). Passenger ships account for the greatest part of maritime traffic (Table 1).

Table 1.

Traffic in the Port of Split by ship type - arrivals.

\begin{tabular}{llllll} 
Ship & Number & Average BT & Max GT & $\begin{array}{l}\text { Average } \\
\text { Length (m) }\end{array}$ & $\begin{array}{l}\text { Max } \\
\text { Length (m) }\end{array}$ \\
\hline Passenger & 4.127 & 2.670 & 122.000 & 48 & 315 \\
\hline Ro-Ro pass. & 4.062 & 4.267 & 31.189 & 90 & 164 \\
\hline Fast pass. & 1.245 & 421 & 458 & 42 & 46 \\
\hline RO-Ro cargo & 204 & 196,5 & 197 & 34 & 35 \\
\hline General & 261 & 3251 & 20.748 & 94 & 180 \\
\hline Container & 49 & 11.797 & 14.241 & 150 & 159 \\
\hline Bulk & 38 & 7.622 & 21.185 & 123 & 178 \\
\hline Tanker & 166 & 2.545 & 23.676 & 82 & 183 \\
\hline Cement & 98 & 2.772 & 12.047 & 82 & 148 \\
\hline Reefer & 23 & 8.841 & 12.401 & 21 & 150 \\
\hline Fish & 118 & 70 & 328 & 32 & 40 \\
\hline Other & 90 & 453 & 6.725 & & 118 \\
\hline
\end{tabular}

Traffic in the Port of Split is also characterized by pronounced seasonality, with traffic in the summer months significantly exceeding traffic during winter. Figure 1 illustrates the number of vessel arrivals into the Port of Split in February and August 2015.

\subsection{Traffic in the Split City Port}

The Split City Port accounts for over $90 \%$ of the total maritime traffic in the greater Port of Split area and passenger ships for $98.5 \%$ of traffic in the Split City Port (CIMIS, 2014). As a rule, cargo ships are directed to the North Port of Split and other ports in the Kaštela Bay. Approximately $47 \%$ of vessels entering the Split City Port have under 500 GT. Figure 2a illustrates the structure of traffic by size of vessels entering the Port of Split, while Figure $2 b$ shows the structure of traffic by vessel type.

Over the last couple of years, the Port of Split saw an increase in the number of cruisers, with 232 arrivals in 2014 (Promet brodova na kružnim putovanjima, 2015). Since works on the broadening of capacities for the acceptance of larger vessels, primarily the construction of external berths, have already begun, a further increase in the traffic of such vessels and the arrival of even larger ships are anticipated. 

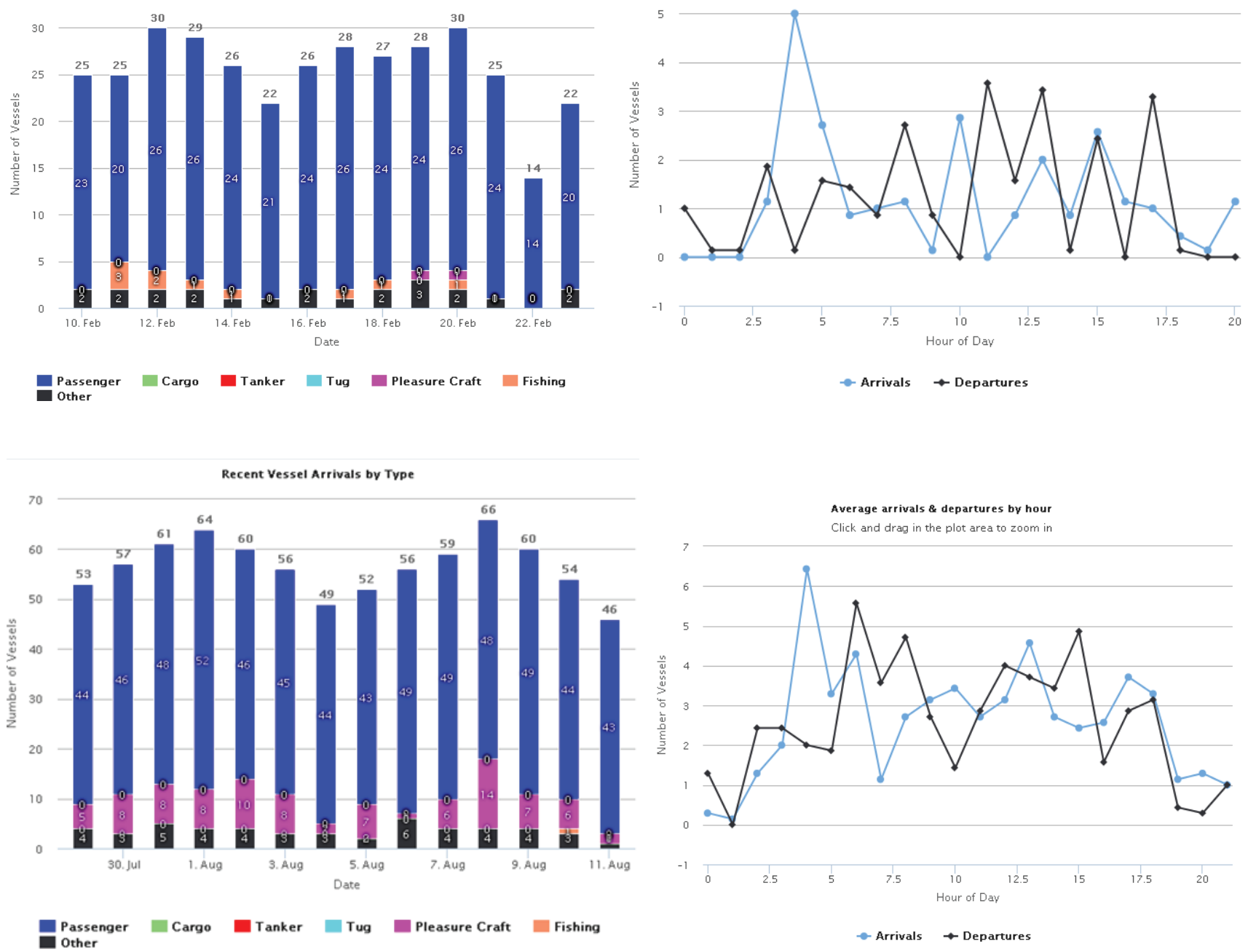

Figure 1.

Daily number of arrivals and departures into/from the Port of Split, February/August 2015.
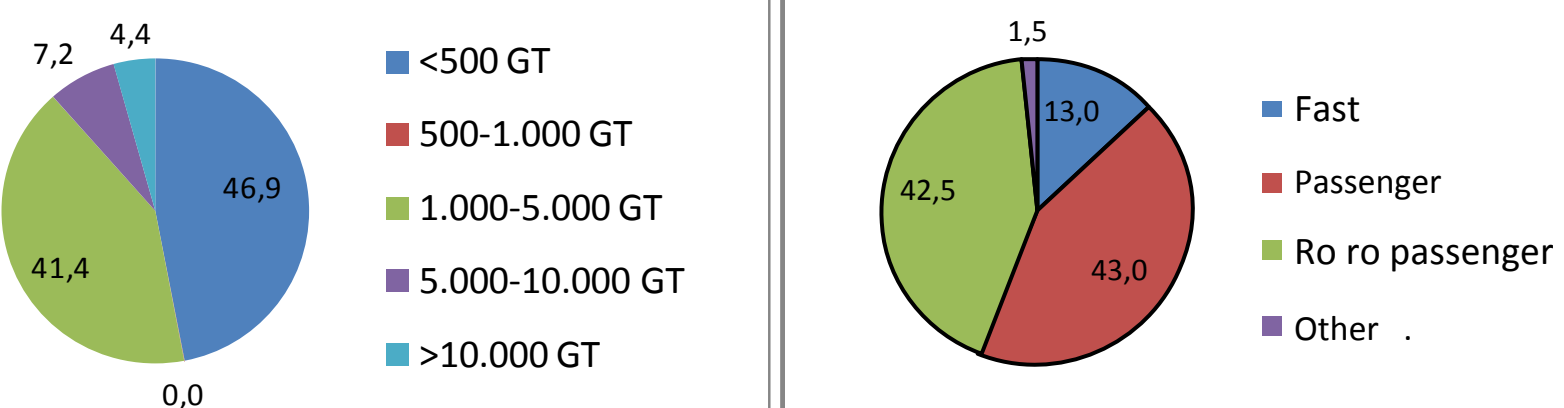

Figure 2

Structure of traffic in the Split City Port. 


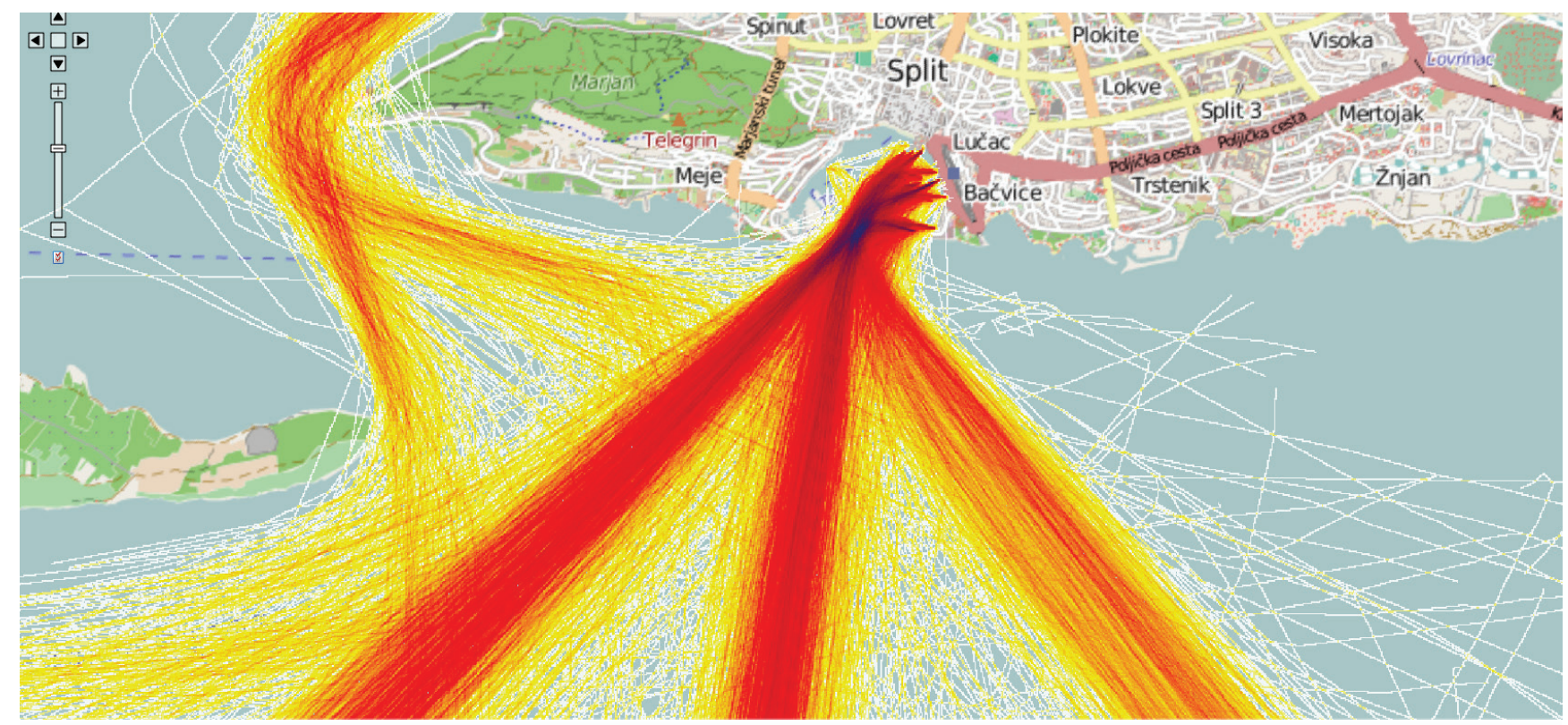

Figure 3.

Density of traffic on approach to the Split City Port (AIS vessel tracking January-March 2015).

\subsection{Smaller Vessel Traffic}

In contrast to the traffic of larger vessels, smaller vessel traffic is notoriously difficult to track owing to the absence of a systematic tracking system. Likewise, smaller vessels do not have established routes and the intensity of their traffic is far greater in the summer than in the remainder of the year. Their traffic may be approximately estimated depending on their number, i.e. the number of arrivals of recorded recreational vessels.

\section{Fishing ships and boats}

In 2014, there were 629 fishing ships, with the total of 35,330 GT and 7,104 fishing boats in the Republic of Croatia (Ribarska flota, 2015). There were 151 fishing boats with Split as port of registration in 2013. In that same year, the number of registered boats was as follows: Split 7,329 (out of which 93\% for personal needs), Trogir 4,038 (out of which $90 \%$ for personal needs) and Kaštela 361, with 736 yachts having Split as their port of registration (Izvješće lučkih kapetanija, 2014).

\section{Yachts}

On 21 August 2013, the Split-Dalmatia County had at its disposal a total of 2,021 berths and the entire Republic of Croatia a total of 16,940 berths for nautical tourism needs. ACI Marina Split with 355 wet and 30 dry berths was constructed in the framework of the City Port. A boat dock with the capacity of approx. 100 boats is situated in the Matejuška cove, likewise located in the City Port basin. There is also a small number of other vessels arriving into the Split City Port for economic or supply reasons.

Two larger marinas ( $\mathrm{ACl}$ marina in the City Port and Marina Kaštela in Kaštel Gomilica) are in the immediate vicinity of the Port of Split, with marinas in Milna, Trogir and Seget catering for the wider Split area. Tables 2, 3 and 4 and Figure 5 show the number of marinas and recreational vessel traffic.

Table 2 .

Number of vessels at permanent berth in marinas (31 December 2013).

\begin{tabular}{lllll} 
& Total & Motor yachts & Sailboats & Other \\
\hline Total RC & 13.735 & 7.141 & 6.122 & 472 \\
\hline Total RC wet berth & 11.605 & 5.671 & 5.687 & 247 \\
\hline SD County & 1.441 & 474 & 904 & 63 \\
\hline Wet berth & 1.172 & 295 & 840 & 37 \\
\hline Dry berth & 269 & 179 & 64 & 26 \\
\hline
\end{tabular}


Table 3.

Number of vessels in transit in marinas in 2013.

\begin{tabular}{lllll} 
& Total & Motor yachts & Sailboats & Other \\
\hline Total RC & 182.921 & 60.020 & 116.646 & 6.255 \\
\hline Total RC wet berth & 177.254 & 56.227 & 114.843 & 6.184 \\
\hline SD County & 44.649 & 7.853 & 34.633 & 2.163 \\
\hline Wet berth & 44.621 & 7.830 & 34.628 & 2.163 \\
\hline Dry berth & 28 & 23 & 5 & $/$
\end{tabular}

Table 4.

Marinas in the Split-Dalmatia County.

\begin{tabular}{llll} 
Marina & Location & No. of berths & Dry berths \\
\hline ACl Marina Split & Split-City Port & 355 & 30 \\
\hline Marina Kaštela & Kaštel Gomilica & 420 & 200 \\
\hline ACl Marina Trogir & Trogir & 180 & 60 \\
\hline Marina Zirona & Drvenik Veli & 140 & $/$ \\
\hline Marina Agana & Marina & 134 & 70 \\
\hline Aci Marina Milna & Brač & 185 & 15 \\
\hline Vlaška Milna & Brač & 90 & 74 \\
\hline Aci Marina Vrboska & Hvar & 85 & 30 \\
\hline Aci Marina Palmižana & Hvar & 164 & $/$ \\
\hline Marina Tučepi & Tučepi & 150 & $/$ \\
\hline Marina Podgora & Podgora & 220 & $/$ \\
\hline Yact Klub Seget & Seget Donji & 23 & 90 \\
\hline Lav & Podstrana & 74 & $/$ \\
\hline Baška voda & Baška voda & 30 & $/$ \\
\hline Marina Ramova & Krvavica & 200 & 100 \\
\hline
\end{tabular}

The intensity of traffic of recreational and other smaller vessels significantly increases in the summer, to a much greater extent than the traffic of larger vessels, with the "mass" departure of recreational vessels during weekly tourist exchange and local and regional sailing competitions standing out as periods of especially high risk (Figure 5).

If the traffic of small vessels, i.e. vessels unequipped with AIS devices, is taken into consideration, the traffic at the entrance and in the immediate vicinity of the Port of Split is significantly denser than previously indicated. The average daily traffic of 6065 vessels obtained from the AIS data can be exceeded within a single hour during the summer season if small vessels are accounted for, which drastically alters the assessment of the likelihood of accident occurrence.

\section{Other traffic}

In 2015, the Split City Port became a point of departure for hydroplanes maintaining regular traffic throughout the year. The runway is situated in immediate proximity to the port and intersects with the routes of regular vessels.

The remaining traffic in the immediate vicinity of the City Port concerns sports-recreational, economic, military and other activities occasionally organized in the Port or in its immediate surroundings. 


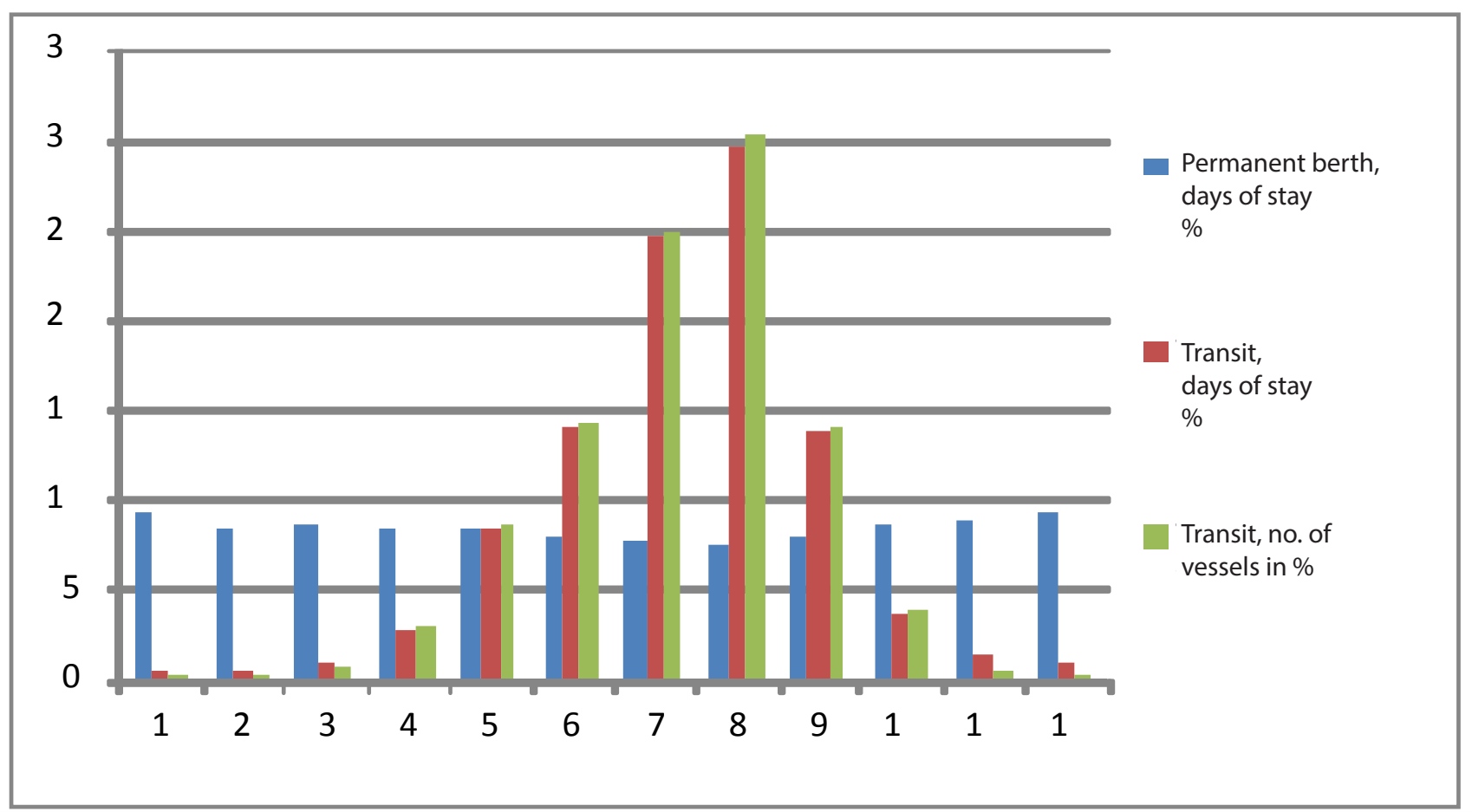

Figure 4.

Monthly dynamics (\%) of the number of vessels and days of stay in marinas in 2013 ,

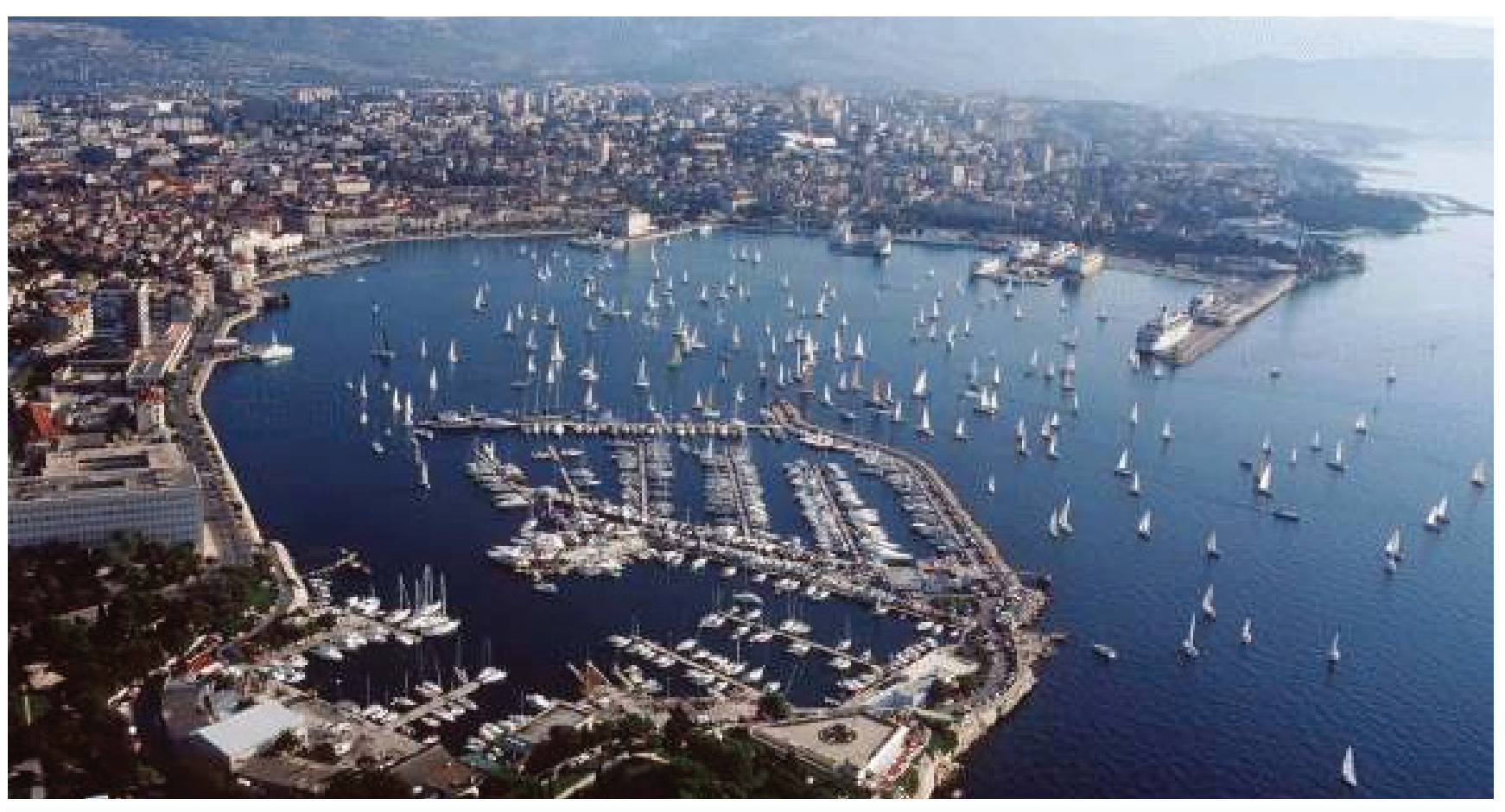

Figure 5.

Sports and recreational navigation. 


\section{MAIN ACCESS FAIRWAYS}

Main access fairways to the Split City Port are oriented towards the Split Gates, Drvenik Channel, Šolta Channel and Brač Channel. The significance of other coastal fairways is negligible. The busiest fairway is the one leading to the Split Gates, which is simultaneously the shortest route connecting the city of Split with the open sea and the shortest route to the Central Adriatic islands gravitating towards Split. It is followed by fairways connecting the Split City Port with the nearest islands, especially the Split-Supetar (Brač) and Split-Rogač (Šolta) routes. Figure 6 illustrates main fairways on approach to the Port of Split and the density of traffic therein.

Passenger ships connecting the Port of Split with nearby island ports account for the majority of traffic. The routes of these vessels are for the most part focused on the Split Gates and the Drvenik Channel. Cargo ships use all three access channels, providing that vessels carrying hazardous cargo, primarily tankers, are directed towards the Drvenik Channel. Recreational vessel routes are the least established. Figure 6 also shows fairways navigated by different types of vessels entering Port of Split territory.

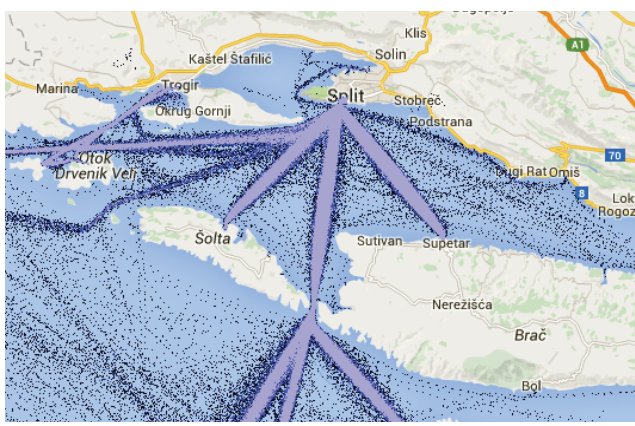

Passenger

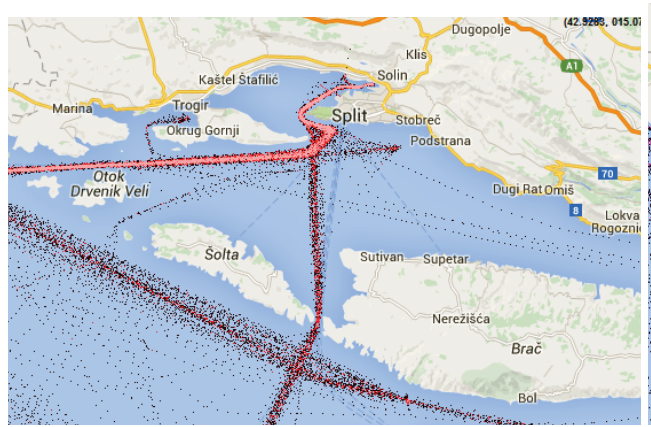

Tankers

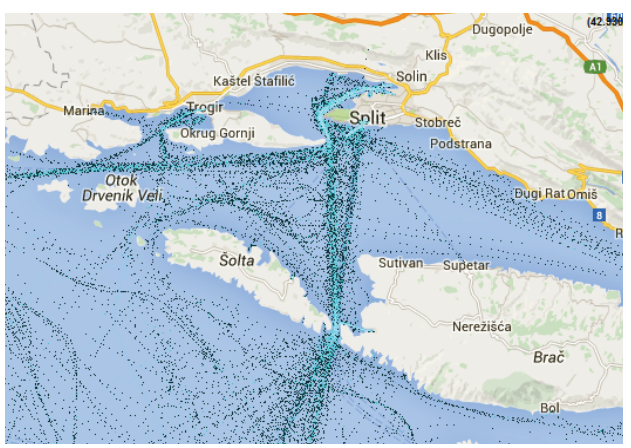

Tow boats and special

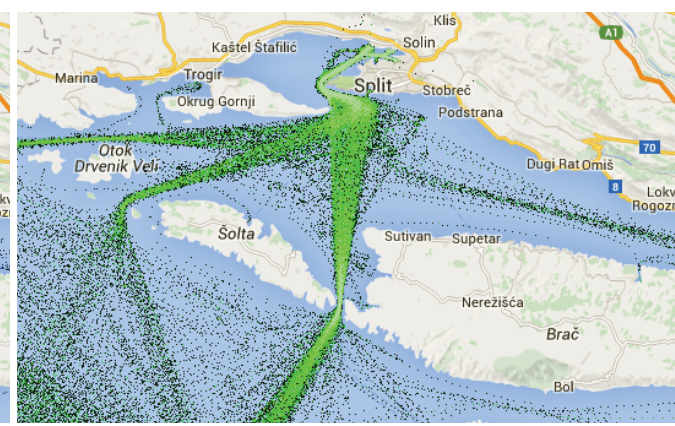

Cargo

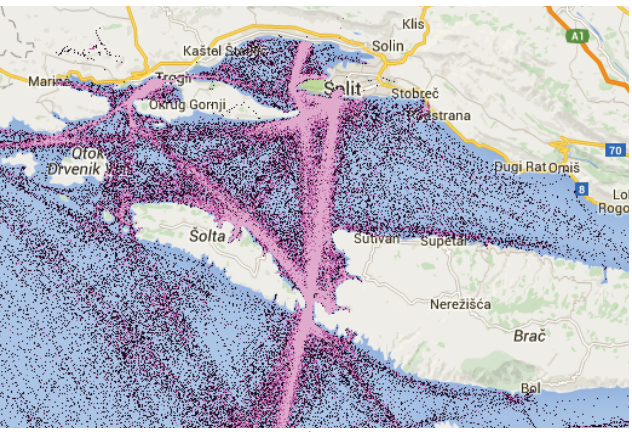

Yachts

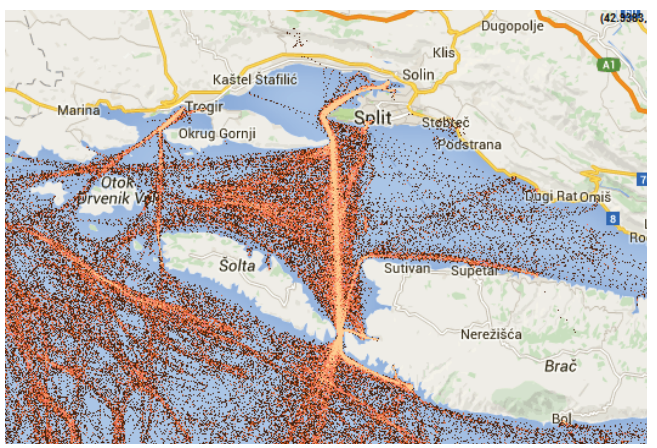

Fishing ships

Figure 6.

Maritime traffic on approach to the Port of Split (AIS podaci-2014.). 


\section{COLLISION AND GROUNDING ASSESSMENT}

An assessment of vessel movement distribution along fairways and an estimation of the likelihood of collision and grounding were made on the basis of the AIS data collected in late July - early August 2015 (Figure 7). The results obtained confirm (for the wider Port of Split area) that the likelihood of grounding is significantly greater than the likelihood of collision, i.e. grounding may be expected to occur in the wider Port area every couple of years. Since the data were collected during the summer traffic peak, the annual average should be somewhat lower. However, since the data did not account for smaller vessels unequipped with AIS, the likelihood of grounding and collision might actually be higher than indicated.

Table 5 .

Annual likelihood and frequency of collisions and groundings.

\section{Type of accident}

Annual likelihood Frequency

\begin{tabular}{|c|c|c|}
\hline $\begin{array}{l}\text { Grounding during } \\
\text { navigation }\end{array}$ & 0,504 & 1,986 \\
\hline Grounding by careening & 0,020 & 49,1 \\
\hline TOTAL grounding & 0,524 & 1,909 \\
\hline $\begin{array}{l}\text { Collision while } \\
\text { overtaking }\end{array}$ & 0,0004 & 2.670 \\
\hline $\begin{array}{l}\text { Collision due to } \\
\text { opposing routes }\end{array}$ & 0,0006 & 1.759 \\
\hline $\begin{array}{l}\text { Collision due to crossing } \\
\text { routes }\end{array}$ & $2,5 \times 10-5$ & $3,986 \times 104$ \\
\hline $\begin{array}{l}\text { Collision while joining } \\
\text { traffic }\end{array}$ & $1,2 \times 10-5$ & $8,479 \times 104$ \\
\hline Bend & $7,4 \times 10-5$ & $1,356 \times 104$ \\
\hline TOTAL collision & 0,001 & 949,2 \\
\hline
\end{tabular}

The likelihood of collision and grounding was calculated using an analytical method for the calculation of potential accidents (which would occur if the crew fail to make appropriate evasive maneuvers), while the assessment of the number of actual accidents was made by multiplying the figure obtained in the preceding step with a corresponding coefficient of likelihood, defined as a correlation between actual and potential collisions/ groundings, most frequently based on statistical data. Since only a very limited number of collisions and groundings occur in the Split City Port area, i.e. there are no statistical data, the coefficient of likelihood was estimated based on average figures for similar areas. The data obtained indicate that the likelihood of collision on approach to the Port of Split is very small and significantly lower than the likelihood of grounding. The main reasons behind this result are, first, that the analysis is based on AIS data, i.e.

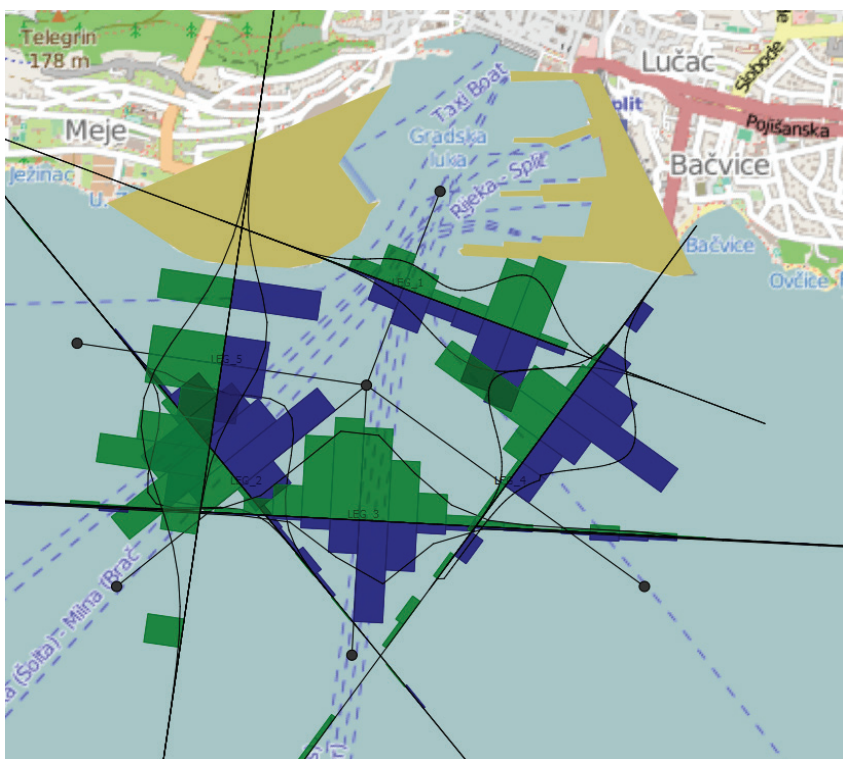

Figure 7.

Distribution of traffic and likelihood of collision and grounding - wider City Port area.

data which fail to account for smaller vessel traffic (boats, yachts, fishing ships, etc.) and second, that vessels move at lower speeds in the observed area.

The assessment of collision and grounding for the Split City Port may also be based on research conducted for the needs of the Traffic-Navigation Study for the Split, Ploče and Dubrovnik Navigable Area, in the framework of which a maritime traffic analysis was conducted, including an assessment of collision and grounding on the main fairways leading to the Port of Split, with special emphasis on the Split Gates and the Drvenik Channel. Namely, almost all traffic in the two channels flows either into or out of the Port of Split. The Study used the same method for the calculation of likelihood of collision and grounding, i.e. the same software (IWRAP) and data collected in the summer of 2014. The results of the analysis of grounding for the Split Gates indicate that grounding may be expected to occur every couple of years, which approximates data obtained for entrance into the Port. On the other hand, the results of the analysis of collision in the Split Gates indicate that collision may be expected to occur every 70 years, which far exceeds the estimate for entrance into the Port (Prometno-plovidbena studija plovno područje Split, Ploče i Dubrovnik, 2014) and might be explained by the greater length of the observed fairway and higher vessel speeds.

Three larger vessel groundings occurred in the Split Gates in 2007-2015 (Poklepović et al., 2012; SAR statistika 2014, 2015), which largely corresponds to simulation results. Data pertaining to larger vessel collisions can not be verified due to the extreme rarity of such events. 
However, if accidents involving smaller vessels are taken into account, the situation is quite different, with 23 groundings and 5 collisions occurring in the area of competence of the
Split Port Authority in 2014 (SAR statistics 2014). The number of accidents is significantly higher in the summer and closely mimics the distribution of traffic throughout the year (Figures 4, 8 and 9).

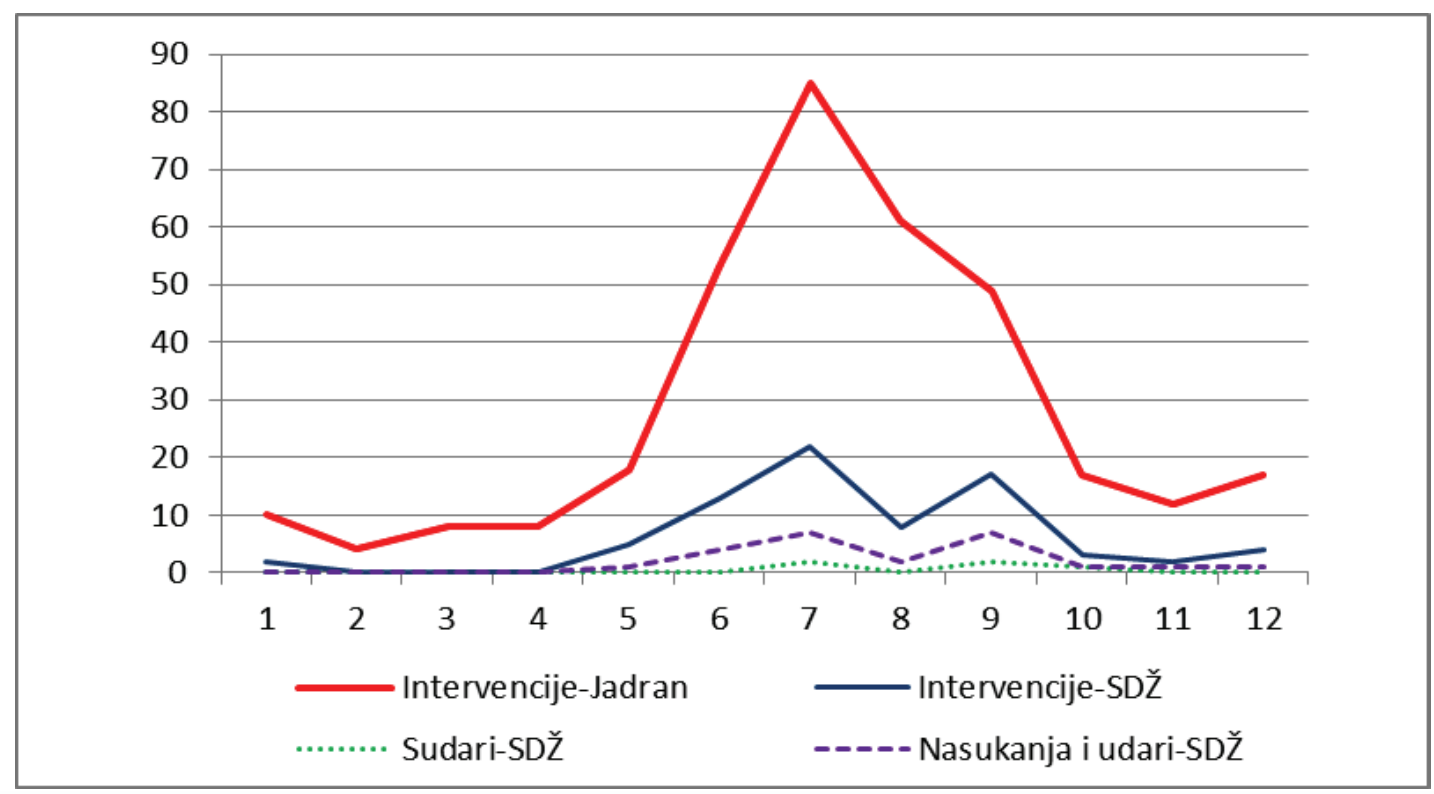

Figure 8.

Number of port authority interventions in 2014.

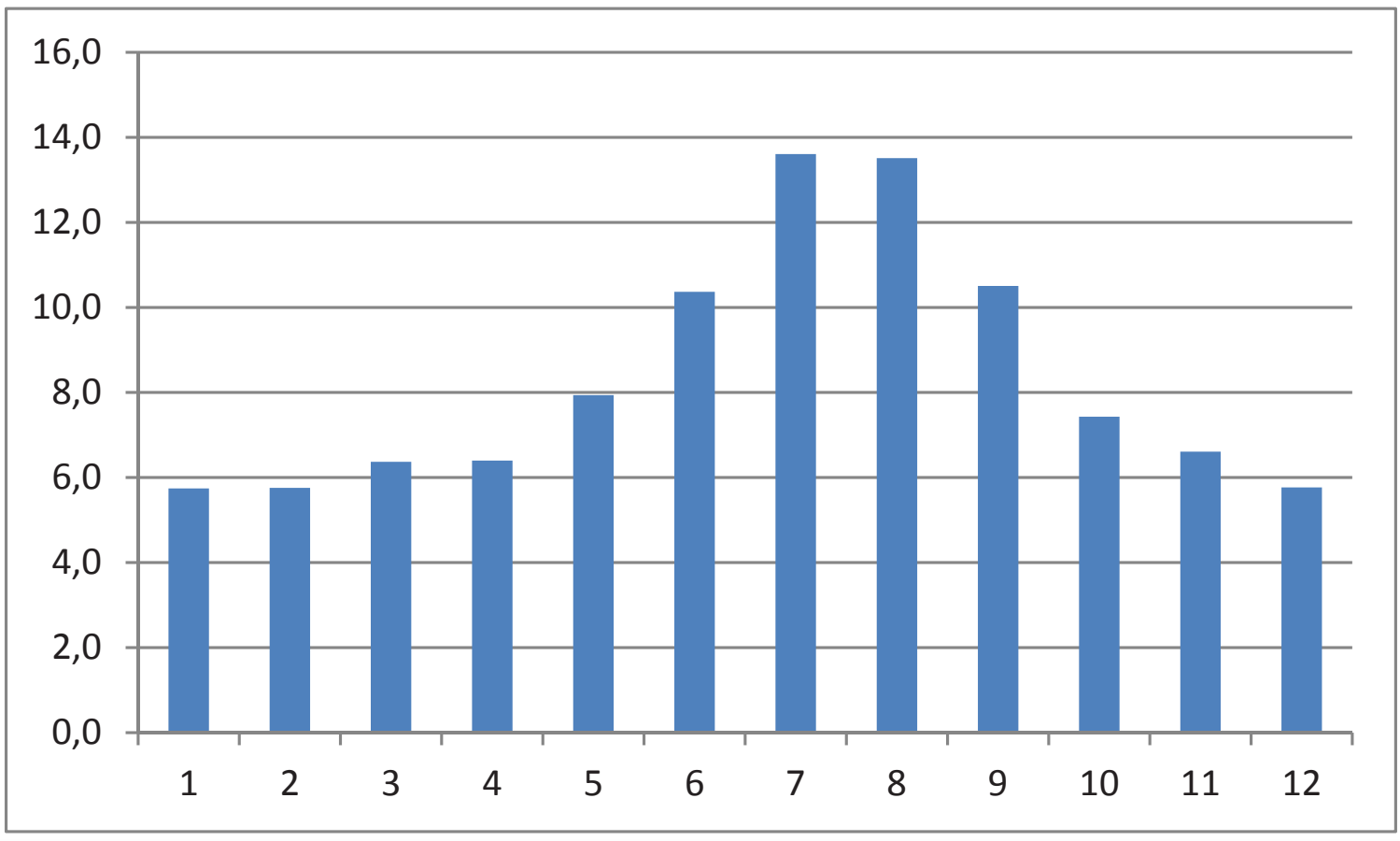

Figure 9.

Monthly traffic in the Port of Split in \% (AIS). 
The Split-Dalmatia County has the total surface of 14,106.40 $\mathrm{km}^{2}$, including $9,576.40 \mathrm{~km}^{2}$ of sea (or approx. $30.8 \%$ of the sea surface of the Republic of Croatia) (http://www.dalmacija.hr).

Considering that 1-2 collisions (of smaller vessels and boats) occur on the territory of the Split-Dalmatia County on the annual level, the average likelihood of collision per square kilometer is $1-2 \times 10^{-4}$. The likelihood of grounding is many times higher.

According to the reports of the Split Port Authority and its local offices, over 50,000 arrivals are registered each year. Marina traffic on the territory of the Split-Dalmatia County is approx. 45,000 for yachts in transit alone. If other traffic is added to these figures, 200,000 or more trips may be concluded to be realized on the territory of the Split-Dalmatia County on the annual level. Likelihood of collision per voyage is approx. $0,5-1 \times 10^{-5}$. Since the Port of Split accounts for approximately $28 \%$ of all arrivals, $31 \%$ of all registered boats and $32 \%$ of all berths in the Split-Dalmatia County, the same percentage of vessel collisions may be expected to occur in the wider Port area. Vessel collision assessment can also be based on comparative analysis with other similar areas worldwide, according to which the general likelihood of loss of steering control, i.e. collision of larger vessels, may be considered to be, in average, $1-3 \times 10^{-5}$ per nautical mile for the critical parts of the fairway, with situations involving two vessels with opposing or nearly opposing routes having to pass each other considered the most critical (Kristijansen, 2005).

Situation is different in case of groundings, since although a significant number of groundings occur on the territory of the Split-Dalmatia County, the Port of Split area accounts for only a small portion thereof. According to the SAR statistics, there were 23 groundings and one impact (Port of Split), and 5 collisions on the territory of the Split-Dalmatia County in 2014. In the wider Port of Split area, critical grounding points are access channels to the Port, especially the Split Gates (Poklepović et al., 2012). On the other hand, the majority of vessel impacts are recorded in the Port of Split, with this type of accident expected to occur every 2-3 years. Impacts are mostly due to steering, i.e. propulsion system failures or human maneuvering errors.

As previously explained, the number of collisions, i.e. groundings may be calculated by multiplying their potential number and the corresponding coefficient of likelihood (Pc/Pci), defined as a correlation between actual and potential accidents. Many analyses of conditional likelihood of grounding Pci take $2.0 \times 10^{-4}$ as average per voyage for larger vessels (Kristijansen, 2005). When this figure is applied to the estimated 200,000 voyages, we arrive at the number of 40 groundings per annum at the level of the Split-Dalmatia County, which comes very close to the statistically obtained data, especially if the indicated number of voyages includes smaller vessel traffic. An alternative approach to the analysis of grounding is to look not for the likelihood of loss of control per voyage, but per unit of distance or time of navigation. E.g., the average of $2.0 \times 10^{-5}(1 / \mathrm{NM})$ is taken for the territory of Japan and $0.3-1.5 \times 10^{-5}$ (1/NM) for Norwegian cost. Corresponding areas of the USA have the likelihood of steering system failure of $1 \times 10^{-4}$ (failure/hour), i.e. the average speed of 10 knots and for $5 \%$ accidents from the total number of failures, the likelihood of $2.5 \times 10^{-5}$ (accidents/NM). These figures approximate the impact statistics for the Port of Split, for which, considering the annual vessel traffic of 30,000 arrivals and departures, and an impact every three years, likelihood of impact is approx. $1.1 \times 10^{-5}$.

\section{CONCLUSION}

One of the busiest fairways on the eastern coast of the Adriatic is situated in the immediate vicinity of the Port of Split. As for the Port proper, the annual average of 40-50 arrivals per day does not seem excessive. However, an in-depth examination of the time division of traffic, especially when smaller vessels, i.e. vessels harder to track are accounted for, reveals that the concentration of vessels in the Port and on its immediate approach can be extremely high. Namely, traffic in the summer months exceeds traffic during winter many times, especially when smaller vessels are taken into consideration. This fact is of paramount importance in safety assessments, i.e. collision and grounding analyses. Current assessment models, e.g. based on AIS data, have their limitations, and most frequently depend on the accuracy of input data. Average annual maritime traffic can not serve as the basis for a reliable safety assessment, i.e. assessment of the likelihood of collision and grounding, without accounting for the traffic of smaller vessels.

Data obtained in this study suggest that the risk of collision and grounding in the immediate vicinity of and in the Port, considerably exceeds present estimates. In the near future, increased traffic of vessels, especially cruisers and yachts, may be expected, along with a likely increase in the hydroplane traffic and other activities in the Port and its surroundings. Consequently, significant increase of collision and grounding risk may be expected in the years to come, if the present safety of navigation measures are not improved.

\section{REFERENCES}

Arhiva dolazaka putničkih brodova na kružnim putovanjima, available at: http:// portsplit.com/wp-content/uploads/mpdf.pdf, [accessed 3 April 2016.].

CIMIS- Hrvatski integrirani pomorski informacijski sustav, Podaci za 2014., MPPI, available at: http://www.mppi.hr/default.aspx?id=10393

Fujii, Y., Yamanouchi, H. and Mizuki, N., (1974), Some Factors Affecting the

Frequency of Accidents in Marine Traffic: II - the Probability of Stranding, Journal of Navigation, 27(2), pp. 239-243.

http://dx.doi.org/10.1017/S0373463300025960

Gradska luka Split, available at: http://splitinfo.tripod.com/splitinfo/str_lij/splitfoto. htm, [accessed 3 April 2016.]. 
IWRAP, available at: http://www.gatehouse.dk/en-US/Fields-of-Expertise/Maritime/ Products/IWRAP-Risk-analysis.aspx, [accessed 2 April 2016.].

Izvješće lučkih kapetanija-Podaci o radu lučkih kapetanija za razdoblje od 01.siječnja 2013. do 31. prosinca 2013., (2014), Zagreb: Uprava sigurnosti plovidbe-MPPI.

Kristiansen, S., (2005), Maritime Transportation: Safety Management and Risk Analysis, Elsevier Butterworth-Heinemann: Oxford.

Lušić, Z. and Čorić, M., (2015), Models for Estimating the Potential Number of Ship Collisions, Journal of Navigation 68 (4), pp. 735-749., http://dx.doi.org/10.1017/S0373463314000903

Macduff, T., (1974), The Probability of Vessel Collisions, Ocean Industry 9(9), pp. 144148.

Marina Baška Voda, available at: http://yacht-charter-croatia.eu/marine/hrvatska/ marina-baska-voda, [accessed 4 April 2016.]

Marina-Ramova, available at: http://www.yacht-rent.hr/najam-plovila/marinas/ marina-ramova, [accessed 5 April 2016.].

Marine u Hrvatskoj, available at: http://www.croatia-yachting-charter.com/hr/ Marine\%20u\%20Hrvatskoj/, [accessed 3 April 2016.].

Ministarstvo poljoprivrede-Uprava ribarstva, available at: http://www.mps.hr/ ribarstvo/default.aspx?id=13, [accessed 3 April 2016.].
Ministarstvo turizma, arhiva, available at: http://www.mint.hr/default. aspx?ID=2505/, [accessed 23 August 2015.].

Poklepović, P., Galić, S. and Lušić, Z., (2012), Splitska vrata-Maritime Traffic and Accidents, Proc. International Maritime Science Conference, Split, Croatia, June 16 - 17, pp. 80-89.

Promet brodova na Jadranu, available at: http://www.marinetraffic.com/hr/, [accessed 23 August 2015.].

Promet brodova na kružnim putovanjima, availabe at: http://portsplit.com/wpcontent/uploads/Sveukupno-putnika-i-brodova-2002-2013.htm, [accessed 7 March 2015.].

Prometno-plovidbena studija plovno-Plovno područje Split, Ploče i Dubrovnik, (2014), Rijeka: Pomorski fakultet u Rijeci.

Prostorne značajke, availabe at: http://www.dalmacija.hr/zupanija/prostorneznacajke, [accessed 10 January 2016.].

Ribarska flota, (2015), available at: http://www.dzs.hr/Hrv_Eng/ publication/2015/01-04-01_01_2015.htm, [accessed 12 April 2016.].

SAR Statistika 2014, (2015), Zagreb: Uprava sigurnosti plovidbe, MPPI.

Simonsen, B. C., (1997), Mechanics of Ship Grounding, PhD Thesis, Technical, University of Denmark. 